\title{
High Lipoprotein(a) in Children from Kindreds with Parental Premature Myocardial Infarction
}

\author{
ALONSO MARQUEZ. SOAIRA MENDOZA. HUGO CARRASCO. TRACEY' HAMER, AND \\ CHARIIES J. GLUECK

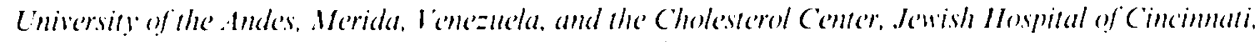 \\ Cincinnati, Ohio 45220
}

\begin{abstract}
ABSTRACI. In 98 children from 98 kindreds, 49 with and 49 without parental premature myocardial infarction (age $\leq 45$ y), our specific aim was to determine whether, and to what degree, lipoprotein(a) $[\mathrm{Lp}(\mathrm{a}) \mid$ and other atherogenic lipids and lipoproteins might be overexpressed in children from premature infarction kindreds. Median L.p(a) (270) $\mathrm{mg} / \mathrm{L}$ ) in case boys was nearly twice that in control boys $(140 \mathrm{mg} / \mathrm{L})(\mathrm{p} \leq 0.001)$. In a logistic regression model including age, Quetelet index (relative ponderosity), Lp(a), apo $A 1$, apo $B$, triglyceride, and pubertal status, the 24 case boys had higher $I . p(a)(p=0.03)$, higher triglyceride $(p=0.036)$, and marginally lower apo $A l(p=0.06)$ than the 26 control boys. NIedian $\mathrm{Lp}(\mathrm{a})$ in case girls $(200 \mathrm{mg} /$ L) was much higher than in control girls $(150 \mathrm{mg} / \mathrm{L})(p \leq$ $0.01)$. In a logistic regression model including age, Quetelet index, $L p(a)$, apo $A 1$, apo $B$, triglyceride, and menarchal status, $L p(a)$ was higher $(p=0.02)$, apo $B$ was marginally higher $(p=0.07)$, and apo $A 1$ was lower $(p=0.008)$ in 25 case girls than in 23 control girls. Reflecting familial clustering of major lipid-lipoprotein risk factors for coronary heart disease, children from kindreds with premature parental myocardial infarction were distinguished from children from control kindreds by high $L p(a)$ and also had higher apo $B$ and triglyceride and lower apo $\mathrm{Al}$ levels. (Pediatr Res 34: 670-674, 1993)
\end{abstract}

\section{Abbreviations}

L.p(a), lipoprotein (a)

CIID, coronary heart disease

$L p(a)$ is a cholesterol-carrying lipoprotein composed of the major structural protein of LDL (apo B 100) linked by a disulfide bridge to apo(a), a glycoprotein with considerable homology to plasminogen $(1,2) . \mathrm{Lp}(\mathrm{a})$ is an independently atherogenic lipoprotein, and may be thrombogenic $(1,2)$. As recently reported from the Bogalusa Heart Study (3), Caucasian children (8-17 y of age) from kindreds with parental premature myocardial infarction had higher levels of $\mathrm{Lp}(\mathrm{a})(224 \mathrm{mg} / \mathrm{L})$ than those without parental myocardial infarction $(170 \mathrm{mg} / \mathrm{L}, p<0.01)$. Moreover, the prevalence of parental myocardial infarction was higher in parents of children whose $\mathrm{Lp}(\mathrm{a})$ was defined as "high" $(>250$ $\mathrm{mg} / \mathrm{L})$ than in those whose $\mathrm{Lp}(\mathrm{a})$ levels were $\leq 250 \mathrm{mg} / \mathrm{L}(9.5$ versus $5.4 \%, p<0.01)(3)$. Similar findings have been reported by Kostner 't $a l$. (4) and Hoefler $(' t a l$. (5). In the study by

Received March 29. 1993; accepted June 14. 1993.

Correspondence and reprint requests. Charles J. Glueck, M1.D. Cholesterol Center, Jewish Hospital. 3200 Burnet Ave.. Cincinnati. OH 45229.

Supported in part by (jrant M-392-91. Merida Venezuela, M1-4)2. and by Grants 732 and 2-728 from the Jewish Hospital Medical Research Council. Jewish Hospital of Cincinnati.
Hoefler et al. (5), children from kindreds with parental myocardial infarction were much more likely to have $\mathrm{Lp}(\mathrm{a})$ levels $>250$ $\mathrm{mg} / \mathrm{L}(32 \%)$ than controls $(13.4 \%)$.

Multiple previous studies of progeny of parents with premature myocardial infarction have revealed lower HDL cholesterol. lower apo Al/apo B ratios, and higher LDL cholesterol in pediatric case subjects compared with pediatric controls (6-12). Because the origin of atherosclerosis is in childhood $(13,14)$, and because lipid and lipoprotein risk factors (VLDL, LDL. and HDL cholesterol) and smoking are related to both fatty streaks and raised lesions in the abdominal aorta in children and in young men $(13,14)$, diagnosis and therapy of pediatric risk factors (15) for adult cardiovascular disease are very important.

Our specific aim in the current study of 49 progeny of parents with premature myocardial infarction and 49 control children (no parental premature infarction) was to assess coronary artery disease risk factors in children, with a particular focus on serum $\mathrm{Lp}(\mathrm{a})$.

\section{MATERIAISS AND MI:THODS}

Cases and comtrols. The study was carried out in 98 Mestizo (mixed South American Indian-Spanish) schoolchildren in Merida. Venezuela, a college, resort, and regional administrative center, population 74000, high in the foothills of the Andes mountains. The relative ethnic contributions of Indian or Spanish ancestors to the Mestizo children could not be determined by historical or family records. The ethnic background of the Mestizo children in the Andean foothills is one of generations of variegated Indian-Spanish mixtures.

The 49 Mestizo case children ( 24 boys, 25 girls) came from kindreds where a parent had sustained premature myocardial infarction (at $\leq 45 \mathrm{y}$ of age). Parental premature myocardial infarction was systematically documented by clinical, electrocardiographic, myocardial enzymatic, and coronary arteriographic studies. All 49 parents with premature myocardial infaretion had greater than $50 \%$ occlusion of at least two coronary arteries on coronary angiography.

The Mestizo control group (26 boys, 23 girls) came from kindreds where the parents had not experienced premature coronary artery disease, had no clinical symptoms related to coronary artery disease, and had no familial history of premature coronary artery disease. The control children were selected from the same schools as the case subjects, and were further selected to match the case subjects' socioeconomic status.

Lipid. lipoprotein. and apolipoprotein determinations. After a 12-h fast. blood was obtained for a measurement of total cholesterol, triglyceride, HDL and LDL cholesterol by enzymatic reactions from Bochringer Mannheim (Indianapolis, IN) analyzed with the Abbott Dichromatic ABA-100 (Abbott Laboratories. N. Chicago, IL). Apo $A l$ and apo $B$ were quantitated by electroimmunoassay (16).

Serum $L p(a)$ was measured by enzyme immunoassay, using a 
monoclonal anti-Lp(a) antibody (17). We have shown that the Terumo enzyme immunoassay (17) is interchangeable with an ELISA (Imubind) method (18). In paired aliquots in 210 patients, the intraclass correlation was significant $(r=0.91, p<0.0001)$ and the lower limit of the $95 \%$ confidence interval of the intraclass correlation $(r=0.89)$ was significant (i.e. $>0.75)$ (18). For the Terumo method, the within-day coefficient of variation was $1.47 \%$, and for the Imubind method, it was $3.4 \%$ (18). Betweenday coefficients of variation were $4.7 \%$ for the Terumo method and $3.0 \%$ for the Imubind method (18).

Study protocol. This study followed a protocol approved by the Institutional Review Committee of the University of the Andes and was carried out with signed informed consent.

When case and control schoolchildren were studied in the outpatient center of the University of Andes, in addition to lipid, lipoprotein, and apolipoprotein measurements (as above), their age, weight, height, pubertal and menarchal status, and systolic and diastolic blood pressures were recorded. In both case subjects and controls, a 7-d diet record was obtained. Using energy and nutrient tables for Venezuelan populations (19), a semiquantitative estimation of group nutritional patterns was obtained, with data available for total calories, protein, saturated and polyunsaturated fat. carbohydrates, and cholesterol intake.

Statistical methods. Because most of the lipid, lipoprotein, and apolipoprotein data were not normally distributed, Wilcoxon nonparametric tests of difference were used to compare groups (20) (Table 1). Although the ages of case subjects and controls did not differ $(p>0.1)$, male case subjects were (on average) 1 $y$ older and female case subjects were 2 y older (Table 1). To assess for the possible effects of age and age-associated higher Quetelet indices, we also covariance-adjusted the data in Table
1 for age and Quetelet index, and then compared the adjusted least square means (20).

Logistic regression (20) (Table 2) was used with group as the dependent variable, and explanatory variables included Quetelet index, age, $\mathrm{Lp}(\mathrm{a})$, apo $\mathrm{A} 1$, apo $\mathrm{B}$, triglyceride, menarchal state (for girls), and pubertal state (for boys).

Differences in nutrient intakes $(\mathrm{g} / 1000 \mathrm{cal}$ of energy intake. percent of calories) between groups were compared by $t$ tests (20) because the data were normally distributed.

\section{RESULTS}

Differences between case subjects and controls for lipids, lipoproteins, and $L p(a)$. As summarized in Table 1 , there was a consistent pattern of significant $(p \leq 0.05)$ differences between case subjects and controls (within sex) as follows: l) HDL cholesterol and apo $\mathrm{A} 1$ were lower in case subjects than in control children; 2) apo B was higher in case subjects than in control children; 3) the ratio of apo Al divided by apo B was lower in case subjects than in control children; 4) the ratio of HDL divided by LDL cholesterol was lower in case subjects than in control children; and 5) Lp(a) was higher in case subjects than in controls.

This pattern of differences between case subjects and controls by Wilcoxon tests (Table 1) was replicated, with levels of significance essentially unchanged, after covariance adjusting for age and Quetelet index (data not shown).

Male case subjects had much higher median $\mathrm{Lp}(\mathrm{a})(270 \mathrm{mg} /$ L) than male controls ( $140 \mathrm{mg} / \mathrm{L}, p=0.001$ ) (Table 1). Similarly, female case subjects had much higher $L p(a)$ than female controls (200 verstus $150 \mathrm{mg} / \mathrm{L}, p=0.003$ ) (Table 1). The $\mathrm{Lp}(\mathrm{a})$ distribu-

Table 1. Clinical characteristics, lipids, lipoproteins, and apolipoproteins in progeny of parents with premature myocardial

\begin{tabular}{|c|c|c|c|c|c|c|c|c|c|c|c|c|}
\hline & \multicolumn{6}{|c|}{ Boy's } & \multicolumn{6}{|c|}{ Girls } \\
\hline & \multicolumn{3}{|c|}{ Cases $(n=24)$} & \multicolumn{3}{|c|}{ Controls $(n=26)$} & \multicolumn{3}{|c|}{ Cases $(n=25)$} & \multicolumn{3}{|c|}{ Controls $(n=23)$} \\
\hline & Mean & Median & SD & Mean & Median & SD & Mean & Median & SD & Mean & Median & SD \\
\hline Age $(y r)$ & 11 & 13 & 6 & 10 & 11 & 4.2 & 13 & 14 & 6 & 11 & 11 & 5 \\
\hline Weight (kg) & 39 & 38 & 21 & 33 & 31 & 13 & 42 & 41 & 18 & 39 & 36 & 17 \\
\hline Height $(\mathrm{cm})$ & 139 & 148 & 35 & 137 & 141 & 25 & 140 & 150 & 23 & $1+1$ & 147 & 23 \\
\hline $\mathrm{SBP}(\mathrm{mm} \mathrm{IIg})$ & 105 & 100 & 14 & 102 & 100 & 15 & 102 & 100 & 11 & 98 & 100 & 8.7 \\
\hline $\mathrm{DBP}(\mathrm{mm} \mathrm{Hg})$ & 63 & 60 & 8 & 62 & 60 & 7 & 64 & 60 & 7.6 & 61 & 60 & 7 \\
\hline $\begin{array}{l}\text { Quetelet index } \\
\left(\mathrm{kg} / \mathrm{cm}^{2} \times\right. \\
1000)\end{array}$ & 1.85 & 1.81 & 0.31 & 1.67 & $1.64 t$ & 0.26 & 2.1 & 1.9 & 0.52 & 1.9 & 1.8 & 0.33 \\
\hline $\begin{array}{l}\text { Waist/hip ra- } \\
\text { tio (U) }\end{array}$ & 0.92 & 0.92 & 0.05 & 0.9 & 0.92 & 0.11 & 0.87 & 0.87 & 0.09 & 0.86 & 0.86 & 0.1 \\
\hline $\mathrm{TC}(\mathrm{mmol} / \mathrm{L})$ & 4.69 & 4.18 & 1.71 & 4.10 & 4.00 & 1.1 & 4.85 & 4.78 & 1.15 & 4.40 & 4.60 & 0.83 \\
\hline $\mathrm{TG}(\mathrm{mmol} / \mathrm{L})$ & 1.17 & 1.11 & 0.44 & 0.95 & 0.94 & 0.36 & 1.29 & 1.20 & 0.57 & 1.13 & 1.10 & 0.39 \\
\hline $\begin{array}{l}\text { HDLC } \\
(\mathrm{mmol} / \mathrm{L})\end{array}$ & 0.95 & 0.93 & 0.18 & 1.33 & $1.32 \ddagger$ & 0.27 & 1.14 & 1.09 & 0.33 & 1.31 & $1.29 \$$ & 26 \\
\hline $\begin{array}{l}\text { LDLC } \\
\qquad(\mathrm{mmol} / \mathrm{L})\end{array}$ & 3.23 & 2.75 & 1.61 & 2.53 & 2.37 & 0.82 & 3.1 & 2.92 & 1.01 & 2.55 & 2.43 & 0.84 \\
\hline $\begin{array}{l}\mathrm{HDLC} / \mathrm{TC} \\
\text { (U) }\end{array}$ & 0.21 & 0.21 & 0.06 & 0.32 & $0.31 \ddagger$ & 0.04 & 0.2 & 0.26 & 0.08 & 0.3 & 0.28 & 0.07 \\
\hline $\begin{array}{l}\text { HDLC/LDLC } \\
\text { (U) }\end{array}$ & 0.35 & 0.33 & 0.17 & 0.59 & $0.55 \dagger$ & 0.25 & 0.41 & 0.4 & 0.19 & 0.58 & $0.52 \$$ & 0.27 \\
\hline $\begin{array}{l}\text { Apo } \mathrm{A} \perp(\mathrm{mg} / \\
\mathrm{L})\end{array}$ & 830 & 840 & 170 & 990 & $1000 \dagger$ & 160 & 850 & 840 & 190 & 1010 & $950+$ & 170 \\
\hline Apo $B(m g / L)$ & 630 & 610 & 130 & 530 & $540 \dagger$ & 110 & 680 & 660 & 200 & 530 & $540 \dagger$ & 80 \\
\hline $\begin{array}{l}\text { Apo Al/apoB } \\
\text { (U) }\end{array}$ & 1.37 & 1.44 & 0.39 & 1.93 & $1.88 \ddagger$ & 0.41 & 1.35 & 1.54 & 0.45 & 1.95 & $1.85 \dagger$ & 0.41 \\
\hline $\mathrm{Lp}(\mathrm{a})(\mathrm{mg} / \mathrm{L})$ & 290 & 270 & 103 & 150 & $140 \ddagger$ & 47 & 270 & 200 & 140 & 160 & $150 \dagger$ & 60 \\
\hline
\end{tabular}

"SBP, systolic blood pressure: DBP, diastolic blood pressure; TC, total cholesterol: TG, triglyceride; HDLC, HDL cholesterol: LDLC, LDL cholesterol.

$+p \leq 0.01$.

$\ddagger p \leq 0.001$

$\$ n \leq 0.05$. 
Table 2. CID risk factors differentiating case subjects from controls (logistic regression)

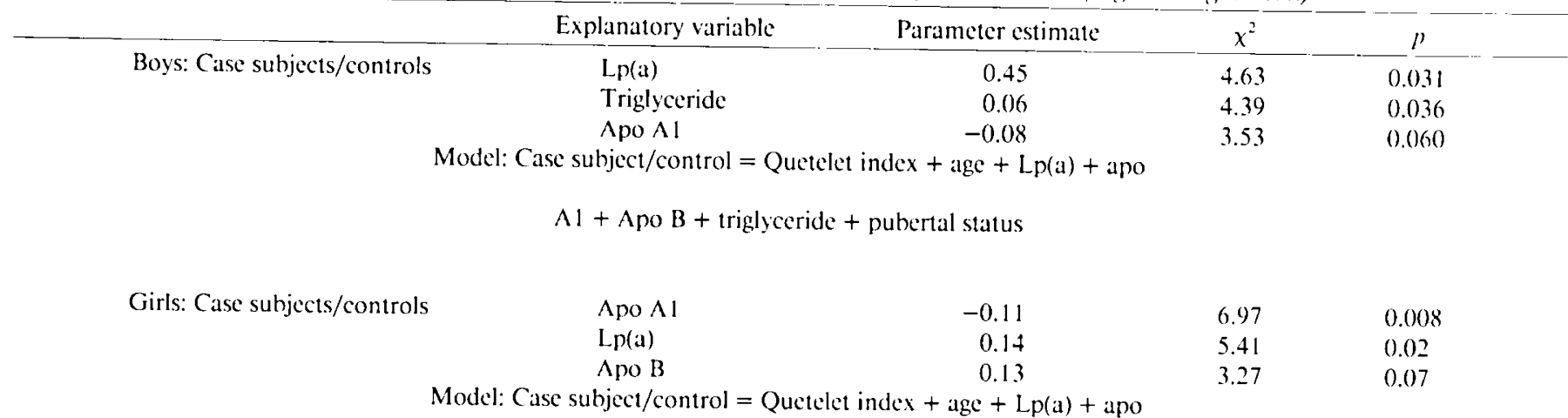

$A l+$ apo $B+$ triglyceride + menarchal status

\section{LP(a)}

Control Group, Boys

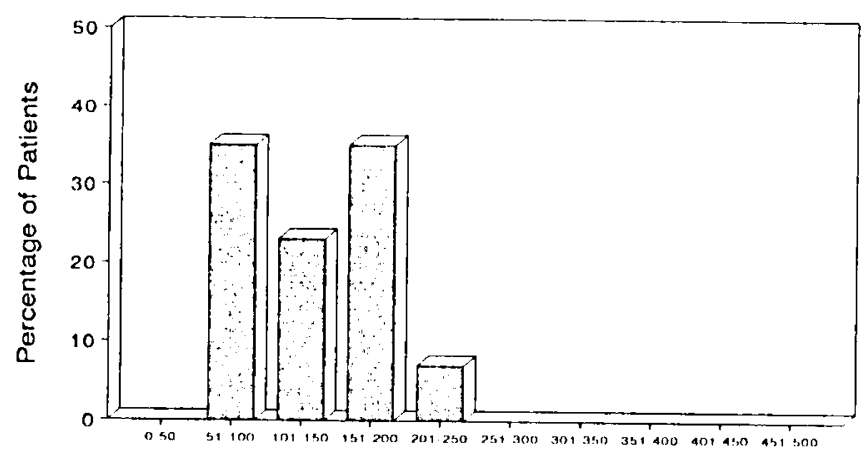

$\mathrm{LP}(\mathrm{a})(\mathrm{mg} / \mathrm{L})$

$\operatorname{LP}(\mathrm{a})$

Case Group, Boys

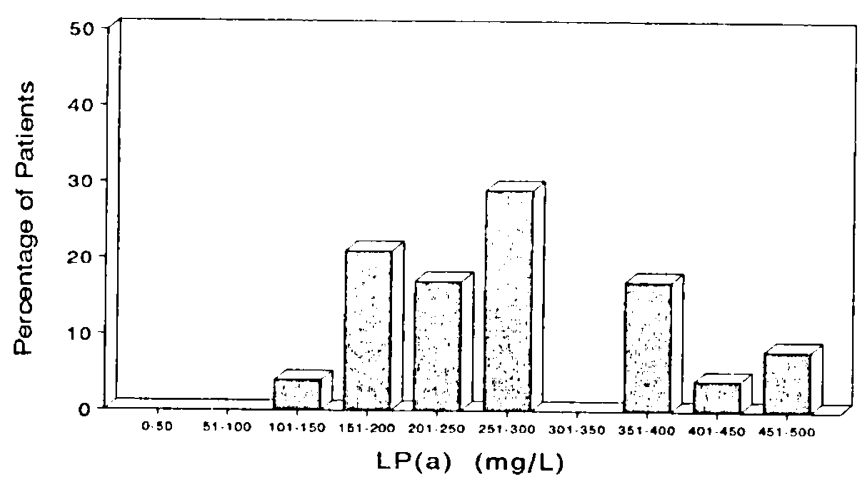

Fig. 1. Frequency distributions of $L p(a)$ in case and control boys.

tion in case subjects was sharply skewed toward higher values than in controls (Figs. 1 and 2).

Coronary heart discase risk factors as independent significant determinants between case and control children. By logistic regression in boys, case subjects had higher $\operatorname{Lp}(\mathrm{a})(p=0.03)$, higher triglyceride $(p=0.036)$, and marginally lower apo $\mathrm{Al}(p)$ $=0.06$ ) (Table 2). By logistic regression in girls, case subjects had higher $\operatorname{Lp}(\mathrm{a})(p=0.02)$, marginally higher apo $\mathrm{B}(p=0.07)$, and lower apo Al $(p=0.008)$ (Table 2).

Nutrient intake. As displayed in Figure 3, the percentages of calories from protein, fat, saturated fat, polyunsaturated fat, and carbohydrate did not differ $(p>0.1)$ when comparing case subjects with controls.

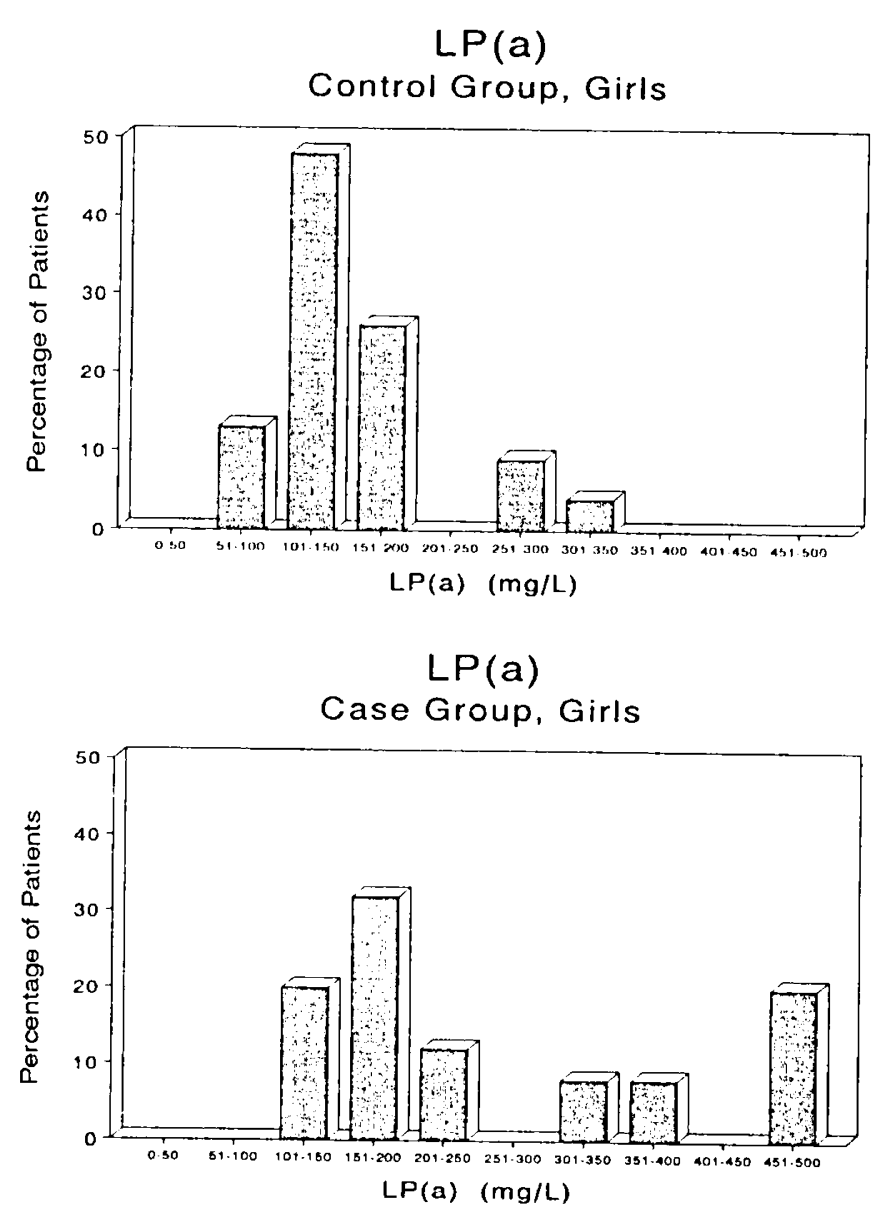

Fig. 2. Frequency distributions of $L p(a)$ in case and control girls.

Mean (SEM) total caloric intake/d was higher in case subjects $(1615 \pm 437)$ than in controls $(1313 \pm 474)(p \leq 0.01)$. Mean $(\mathrm{SEM})$ intake of protein $(\mathrm{g} / 1000 \mathrm{cal} / \mathrm{d})$ in controls $(41.8 \pm 1.36)$ and case subjects $(43.5 \pm 0.87)$ did not differ $(p>0.1$, Fig. 4$)$, nor did intake of total fat in controls $(31.4 \pm 1.46)$ and case subjects $(33.9 \pm 1.44)$. Controls ingested more carbohydrate $(149.3 \pm 4.37 \mathrm{~g} / 1000 \mathrm{cal} / \mathrm{d})$ than case subjects $(131 \pm 3.89)(p$ $=0.002)$ and less cholesterol $(149.8 \pm 4.7 \mathrm{mg} / 1000 \mathrm{cal} / \mathrm{d})$ than case subjects $(176.5 \pm 6.7)(p=0.002)$ (Fig. 4).

\section{DISCUSSION}

Given the heritability of the major CHD risk factors, total. HDL, and LDL cholesterol, apo $A 1$, apo $B$, and $L p(a)(1-12$, 


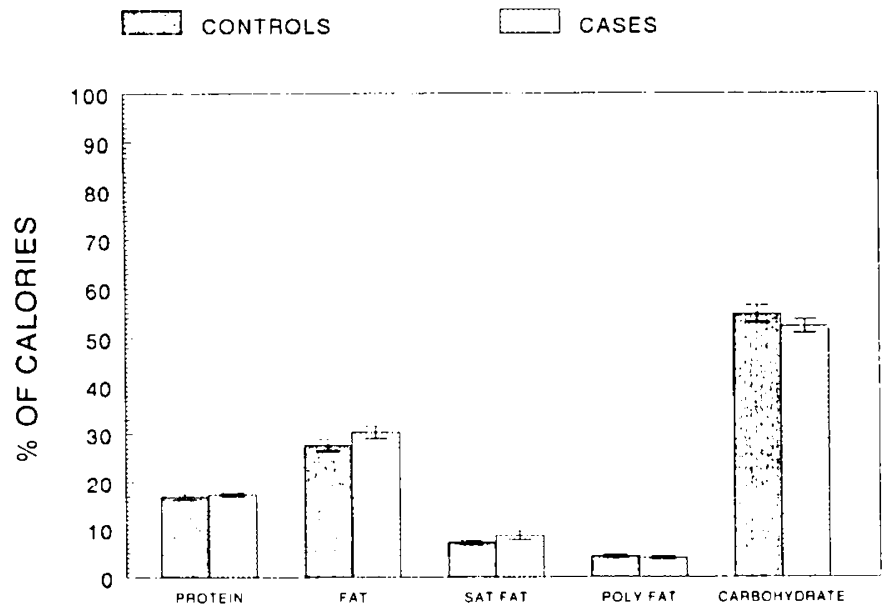

Fig. 3. Mean (SEM) percent of calories from protein, fat, saturated fat. polyunsaturated fat, and carbohydrate in case subjects is controls.

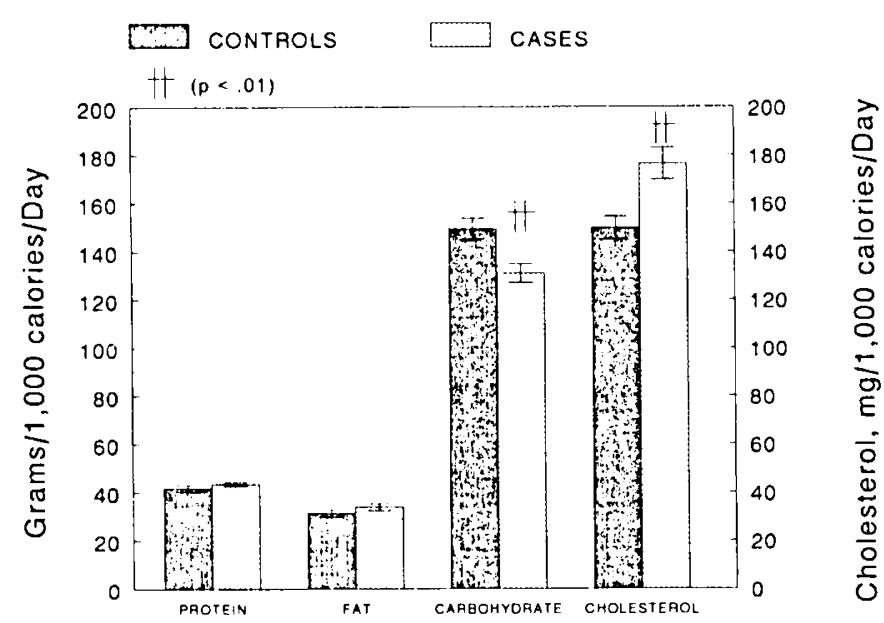

Fig. 4. Mean (SEM) dietary protein. fat, and carbohydrate $(\mathrm{g} / 1000$ $\mathrm{cal} / \mathrm{d}$ ) and dietary cholesterol $(\mathrm{mg} / 1000 \mathrm{cal} / \mathrm{d})$ in case subjects is controls.

21), it was not surprising in our study that progeny of parents with premature myocardial infarction had lower HDL cholesterol. lower apo Al, lower apo A1/apo B ratios, higher LDL cholesterol, and higher $L p(a)$ than children from families without premature myocardial infarction. Although case children ingested more dietary cholesterol than controls, case subjects and controls did not differ in regard to total fat intake per $1000 \mathrm{cal} /$ $\mathrm{d}$ and had comparable percentages of calories from total fat, saturated fat, and polyunsaturated fat.

In our study, in both boys and girls from families with premature myocardial infarction, $\mathrm{Lp}(\mathrm{a})$ was an independent significant determinant of case subjects versus controls, congruent with the report of the Bogalusa Heart Study (3), and with studies by Kostner 't al. (4) and Hoefler 't al. (5).

Although case subjects were not significantly older than controls $(p>0.10)$, male and female case subjects were (on average) 1 and 2 y older, respectively, than controls. Older children might have relatively lower total and HDL cholesterol levels than younger children because of the effects of puberty $(22,23)$. Older children might also have a higher Quetelet index than younger children (24). Thus, differences in total, HDL, and LDL cholesterol and apo B between case subjects and controls may be slightly underestimated and differences in Quetelet index overestimated in this study. However, case-control differences for the measured lipid, lipoprotein, and apolipoprotein variables were not affected by covariance adjusting for age and Quetelet index. Moreover, both age and Quetelet index were included in the logistic regression models and were not significant discriminants between case subjects and controls.

The complex contributions of puberty $(22,23)$, age, and Quetelet index (24) to distributions of lipids, lipoproteins, and apolipoproteins in both case and control children probably accounted to a large degree for the nonnormality of the distributions. $\mathrm{Lp}(\mathrm{a})$ is almost never normally distributed (1-5) and appears to be independent of pubertal status. Quetelet index. age, and type of nutritional intake, with levels predominantly genetically determined $(1-5,25)$.

Given the heritability of $\mathrm{Lp}(\mathrm{a})$ and its association with premature CHD (3-5, 25-27), it is not surprising, in this and in previous studies (3-5), that progeny of parents with premature myocardial infarction are much more likely to have high levels of $\mathrm{Lp}(\mathrm{a})$ than control children. Uniformly effective therapeutic interventions for $L p(a)$ are not yet available for either adults or children (1). However, because $L p(a)$ is synergistic with other CHD risk factors (particularly LDL cholesterol) $(1,2)$, identification of children from families with premature myocardial infarction who have high $\mathrm{Lp}(\mathrm{a})$ and who have other major risk factors for CHD, should, in our opinion, intensify the level of intervention (15) against treatable CHD risk factors. Moreover. when and if safe and effective therapeutic interventions to lower $\mathrm{Lp}(\mathrm{a})$ are available, and if it can be shown in adults that lowering $L p(a)$ independently reduces CHD risk, then these interventions can be expeditiously applied to children with previously diagnosed high $\mathrm{Lp}(\mathrm{a})$ and strong family histories of premature $\mathrm{CHD}$.

\section{REFIRENCES}

1. Glueck CJ, Glueck HI. Tracy T. Speirs J, McCray C. Stroop D 1993 Relation ships between lipoprotein(a). lipids. apolipoproteins, basal and stimulated fibrinolytic regulaters, and o-Dimer. Metaholism 42:236-246

2. Scanu AN 1992 I.p(a): a link between thrombosis and atherosclerosis. Eur J Epidemiol 8(suppl 1):76-78

3. Srinivasan SR. Dahlen GH, Jarpa RA. Webber LS, Berenson GS 1991 Racial (black-white) defferences in serum lipoprotein(a) distribution and its relation to parental myocardial infaretion in children. Bogalusa Heart Study. Circulation $84: 160-167$

4. Kostner GM. Czinner A. Pleifler KH, Biharj-Varga M1991 Lipoprotein(a) concentrations as risk indicators for atherosclerosis. Arch Dis Child 66:1054 1056

5. Hoefler G. Harnoncourt F. Paschke E. Mirl W. Pfeifler Kll, Kostner Gill 1988 Lipoprotein $\mathrm{Lp}(\mathrm{a})$. A risk factor for myocardial infarction. Arteriosclerosis $8: 398-401$

6. Widhalm K koch S. Pakosta R. Schurz M. Brendinger M1 1992 S.rum lipids lipoproteins and apolipoproteins in children with and without familial history of premature coronary heart disease. J Am Coll Nutr I1(suppl):32S$35 \mathrm{~S}$

7. Glueck CJ. Fallat RIV. Tsang R, Buncher CR 1974 Hyperlipemia in progeny of parents with myocardial infarction before age of $50 . \mathrm{Am} \mathrm{J}$ Dis Child 127:70-75

8. Pometta D. Micheli H. Raymond C. Oberhaensli l. Svenram A 1980 Decreased IIDL cholesterol in prepubertal and pubertal children of CHID patients. Atherosclerosis 36:101-109

9. DeBaccker G, Hulstaert F. DeMunck K, Rosseneu M. van Parijs L. Dramaix M 1986 Serum lipids and apoproteins in students whose parents suffered prematurely from myocardial infarction. Am lleart J 112:478-484

10. Perova N, Aingorn H, Metelskala V. Dorofeeva T. Belonkonj N 1988 Plasma lipid and apoprotein levels in children hereditarily predisposed to coronary heart discase. Acta Paediatr Scand 77:559-56?

11. Freedman DS, Srinivasan SR. Shear CL. Webber LS. Berenson GS 1986 The relation of apolipoproteins $A 1$ and $B$ in children to parental myocardial infarction. $\mathrm{N}$ Engl J Nled 315:721-726

12. Lee J, Laluer RM, Clarke WR 1986 lipoproteins in the progeny of young men with coronary artery disease: children with increased risk. Pediatrics 78:330337

13. Newman III WP. Freedman DS, Voors AW, Gard PD). Srinivasan SR, Cresanta JL. Williamson GD, Webher LS, Berenson GS 1986 Relation of serum lipoprotein levels and systolic blood pressure to early atherosclerosis: the Bogalusa Heart Study. N Engl J Med 314:138-144

14. Pathobiological Determinants of Atherosclerosis in Y'outh (PDAY) Research Group 1990 Relationship of atherosclerosis in young men to serum lipoprotein cholesterol concentrations and smoking. JAM1A 264:3018-3024

15. NCEP 199! Report of the expert panel on blood cholesterol levels in children and adolescents. US Department of Health and Human Services, Public Health Service, National Institutes of Health. National Heart. Lung. and Blood Institute, Bethesda, MD

16. Laurell $C B 1966$ Quantitative estimation of protein by electrophoresis in agarose gel containing antibodies. Ann Biochem 15:45-52

17. Silberman S, Armentrout M. Vella FA. Saha AL 1990 Macra L.p(a) for 
quantitation of human lipoprotein(a) by enzymes. Clin Chem 36:961

18. Glueck CJ, McCray C, Stroop D. Tracy T. Speirs J 1992 Measurement of $\mathrm{Lp}(\mathrm{a})$ : comparison of Terumo and Imubind methods. Clin Res 40:414A(abstr)

19. Mendoza S, Contreras G, Ineichen E, Fernandez M, Nucete H, Morrison JA. Gartside P, Glueck CJ 1980 Lipids and lipoproteins in 1298 Venezuelan and 472 American school children: within and cross-cultural comparisons. Pediatr Res 14:272-277

20. Snedecor GW, Cochran WG 1980 Statistical methods, 7th Ed. Iowa State University Press, Ames, IA

21. Glueck CJ, Laskarzewski P, Rao DC, Morrison JA 1985 Familial aggregations of coronary risk factors. In: Connor W, Bristow D (eds) Coronary Heart Disease. Lippincott, Philadelphia, pp 173-193

22. Morrison JA, Laskarzewski PM, Rauh JL, Brookman R, Mellics M. Frazer M. Khoury P, deGroot I, Kelly K. Glueck CJ 1979 Lipids, lipoproteins, and sexual maturation during adolescence: the Princeton maturation study. Metabolism 28:641-649
23. Morrison JA, DeGroot I. Edwards BK, Kelly KA, Mellies MJ, Khoury P, Glucck CJ 1978 Lipids and lipoproteins in 927 school children, ages 6-18 years. Pediatrics 62:990-995

24. Laskarzewski PM. Morrison JA, Mellies MJ, Kelly K, Gartside PS, Khoury P, Glueck CJ 1980 Relationships of measurements of hody mass to plasma lipoproteins in school children and adults. Am J Epidemiol 111:395-407

25. Sandhofer C, Saha N, Kark J, Rees A, Jaross W, Dieplinger H, Hoppichler F, Boerwinkle E, Utermann G 1992 Apo(a) isoforms predict risk for coronary heart disease. A study in six populations. Arteriosclerosis Thrombosis $12: 1214-1226$

26. Armstrong VW, Cremer P. Eberle E, Manke A, Schulze F, Wieland H, Kreuzer H, Seidel D 1986 The association between serum I.p(a) concentration and angiographically assessed coronary arteriosclerosis. Atherosclerosis 62:249 257

27. Wang XL, Wilcken DE, Dudman NP 1992 Early expression of the apolipoprotein(a) gene: relationships between infants and their parents serum apolipoprotein(a) levels. Pediatrics 89:401-406 